\title{
Conversion of Methane to Benzene over Transition Metal Ion ZSM-5 Zeolites
}

\author{
I. Catalytic Characterization
}

\author{
Bert M. Weckhuysen, ${ }^{1}$ Dingjun Wang, Michael P. Rosynek, and Jack H. Lunsford ${ }^{2}$ \\ Department of Chemistry, Texas A\&M University, College Station, Texas 77843
}

Received September 9, 1997; revised December 29, 1997; accepted January 16, 1998

The conversion of methane to benzene in the absence of oxygen has been investigated over different TMI/H-ZSM-5 zeolites (with $\mathrm{TMI}=\mathrm{Mo}, \mathrm{Fe}, \mathrm{V}, \mathrm{W}$, and $\mathrm{Cr}$ ) as a function of the preparation and treatment method, the metal ion loading, and the zeolite acidity. Nonoxidative methane activation is characterized by an induction period prior to the formation of benzene, toluene, and naphthalene. During this induction period the supported metal oxide is reduced and $\mathrm{CO}, \mathrm{CO}_{2}$, and $\mathrm{H}_{2} \mathrm{O}$ are formed. Optimum catalytic performance was obtained for CO-prereduced 2-4 wt\% TMI/H-ZSM-5 zeolites, and their activities decreased in the order: Mo (18.3) $>\mathrm{W}$ (10.8) $>\mathrm{Fe}(5.7)>\mathrm{V}$ (3.9) $>\mathrm{Cr}$ (1.5). The numbers in parentheses are the rates of methane reaction (molec. reacted $/ \mathrm{metal}$ atom $/ \mathrm{h}$ ) obtained after $3 \mathrm{~h}$ on-stream. Impregnated materials always had a higher activity and shorter initial induction period than solid state ion-exchanged materials, and the induction period decreased with increasing time at moderate reduction temperature and with increasing metal oxide loading. Based on a detailed comparison of the different systems, it is evident that the catalytic properties depend on the presence of Brönsted acid sites and the distribution of the TMI's in the zeolite material.

(c) 1998 Academic Press

\section{INTRODUCTION}

The catalytic conversion of methane to desired commodity chemicals is a challenging approach for the utilization of natural gas resources $(1,2)$. Several recent studies have demonstrated that methane can be converted to benzene in the absence of an oxidant, such as oxygen, and the main literature results are summarized in Table $1(3-15)$. It is clear that different transition metal ions (TMI's), such as Mo, $\mathrm{Cu}, \mathrm{Zn}$, and $\mathrm{Cr}$, are able to activate methane and that $\mathrm{Mo} /$ H-ZSM-5 is the most promising catalytic system. However, some active TMI's, in particular Mo, show little or no activity in other characterization studies $(3,4)$. Thus, it seems

\footnotetext{
${ }^{1}$ On leave from the Centrum voor Oppervlaktechemie en Katalyse, Departement Interfasechemie, K. U. Leuven, Kardinaal Mercierlaan 92, 3001 Heverlee, Belgium.

${ }^{2}$ To whom correspondence should be addressed.
}

that preparation and treatment conditions play a crucial role in the activation of these materials. Furthermore, the exact dehydroaromatization mechanism, the distribution of TMI's in the zeolite material, and the phase responsible for methane activation are still a matter of debate.

To resolve these issues, we have performed a systematic study on the effect of TMI, as well as the catalyst preparation and treatment, on the activation of methane. Mo, Fe, $\mathrm{Cr}, \mathrm{W}$, and V/H-ZSM-5 materials, prepared by either impregnation and solid state ion exchange, were compared. Solid state ion exchange of zeolites with volatile metal chlorides is a convenient method to introduce metal ions at exchange sites $(16,17)$. Therefore, special emphasis was placed on the distribution of TMI's, the role of the induction time and the active phase. In this paper, a detailed discussion of the catalytic performances of these materials will be given. Part II of this study will focus on the identification of the active phases for methane activation by X-ray photoelectron spectroscopy (18).

\section{EXPERIMENTAL}

\section{Catalyst Preparation}

Different TMI/H-ZSM-5 catalysts were prepared starting from commercial H-ZSM-5 (PQ Corp., CBU 5020E) having a Si/Al ratio of 25 . Fully exchanged H-ZSM-5 was obtained by ion exchange of $10 \mathrm{~g}$ of the zeolite with a $300 \mathrm{ml}$ of $1 \mathrm{M}$ aqueous solution of ammonium nitrate $\left(\mathrm{NH}_{4} \mathrm{NO}_{3}, \mathrm{EM}\right.$ Science) at $80^{\circ} \mathrm{C}$ for $12 \mathrm{~h}$, followed by drying at $90^{\circ} \mathrm{C}$ overnight and calcination at $500^{\circ} \mathrm{C}$ for $5 \mathrm{~h}$. Partially exchanged H, Na-ZSM-5 materials were prepared in a similar way using aqueous mixtures of ammonium nitrate $\left(\mathrm{NH}_{4} \mathrm{NO}_{3}, \mathrm{EM}\right.$ Science) and sodium chloride $(\mathrm{NaCl}, \mathrm{EM}$ Science) in ratios of $5: 1,3: 1$, and $2: 1$. In addition, a fully exchanged Na-ZSM-5 sample was prepared using a $1 M$ sodium chloride ( $\mathrm{NaCl}$, EM Science) solution.

The resulting zeolite materials were then further used for impregnation or solid state ion exchange with an 
TABLE 1

Literature Survey of Nonoxidative Dehydrogenation over Transition Metal Ion-Loaded ZSM-5 Zeolites

\begin{tabular}{|c|c|c|c|c|}
\hline Catalytic system & Active phase & $\begin{array}{l}\text { Mechanism for catalytic } \\
\text { activation of methane }\end{array}$ & $\begin{array}{l}\text { Distribution of transition } \\
\text { metal ions }\end{array}$ & References \\
\hline $\begin{array}{l}\mathrm{Ru}, \mathrm{X} / \mathrm{H}-\mathrm{ZSM}-5 \text { or } \mathrm{Pt} \\
\mathrm{X} / \mathrm{H}-\mathrm{ZSM}-5 \text { with } \\
\mathrm{X}=\mathrm{Ga}, \mathrm{Zn} \text {, or } \mathrm{Cr}\end{array}$ & $\begin{array}{l}\text { Metal } / \text { metal } \\
\text { oxide }\end{array}$ & $\begin{array}{l}\mathrm{MO}+\mathrm{CH}_{4} \rightarrow \mathrm{M}-\mathrm{OH}+\mathrm{CH}_{3}^{\cdot} \\
2 \mathrm{CH}_{3}^{\cdot} \rightarrow \mathrm{C}_{2} \mathrm{H}_{6}\end{array}$ & Not discussed & $(3,4)$ \\
\hline Mo/H-ZSM-5 & $\mathrm{MoO}_{3}$ & $\begin{array}{l}\mathrm{CH}_{4}+\mathrm{MoO}_{3} \rightarrow \mathrm{CH}_{3}-\mathrm{H}+\mathrm{MoO}_{3} \\
\quad \rightarrow \mathrm{H}^{-}-\mathrm{CH}_{3}^{+}+\mathrm{MoO}_{3} \\
\quad \rightarrow \mathrm{Mo}=\mathrm{CH}_{2}\end{array}$ & $\begin{array}{l}\mathrm{MoO}_{3} \text { crystallites and octahedral } \\
\text { agglomerates }\left(\mathrm{NH}_{4} \mathrm{OH} \text { extractable }\right) \\
\mathrm{MoO}_{4}^{2-} / \mathrm{Al}_{2}\left(\mathrm{MoO}_{4}\right)_{3}\left(\mathrm{NH}_{4} \mathrm{OH}\right. \\
\text { non-extractable })\end{array}$ & $(5,7)$ \\
\hline $\mathrm{Cu} / \mathrm{H}-\mathrm{ZSM}-5$ & $\mathrm{CuO}$ & Carbenium ion mechanism & Not discussed & \\
\hline $\mathrm{Zn} / \mathrm{H}-\mathrm{ZSM}-5$ & $\mathrm{ZnO}$ & $\underset{[\mathrm{Zn}-\mathrm{H}]^{+}}{\mathrm{CH}_{4}+\mathrm{Zn}^{2+}(\mathrm{s}) \rightarrow \mathrm{CH}^{+}(\mathrm{s})+}$ & Not discussed & \\
\hline Mo/H-ZSM-5 & $\mathrm{MoO}_{\mathrm{x}}$ & $\begin{array}{l}\mathrm{CH}_{4} \rightarrow \mathrm{CH}_{3}^{\cdot}+\mathrm{H}^{\cdot} \\
2 \mathrm{CH}_{3}^{\cdot} \rightarrow \mathrm{C}_{2} \mathrm{H}_{4}+\mathrm{H}_{2}\end{array}$ & Active phase in the zeolite channels & $(8,9)$ \\
\hline Mo/H-ZSM-5 & $\begin{array}{r}\mathrm{Mo}_{2} \mathrm{C} / \mathrm{Mo}_{\mathrm{x}}- \\
\mathrm{C}-\mathrm{MoO}_{\mathrm{x}}\end{array}$ & $\begin{array}{l}\mathrm{CH}_{4}+\mathrm{O}(\mathrm{s}) \rightarrow \mathrm{CH}_{3}^{\cdot}+\mathrm{OH}(\mathrm{s}) \\
2 \mathrm{OH}(\mathrm{s}) \rightarrow \mathrm{H}_{2} \mathrm{O}+\mathrm{O}(\mathrm{s}) \\
2 \mathrm{CH}_{3}^{\circ} \rightarrow \mathrm{C}_{2} \mathrm{H}_{6}\end{array}$ & Not discussed & $(10-12)$ \\
\hline Mo/H-ZSM-5 & $\mathrm{Mo}_{2} \mathrm{C}$ & $\begin{array}{l}\mathrm{C}_{2} \mathrm{H}_{4} \text { formed on } \mathrm{Mo}_{2} \mathrm{C} \text { and } \\
\text { converted to aromatics } \\
\text { at acid centers }\end{array}$ & $\begin{array}{l}\text { Active phase is predominantly } \\
\text { at outer surface }\end{array}$ & \\
\hline $\mathrm{Fe} / \mathrm{H}-\mathrm{ZSM}-5$ & $\mathrm{Fe}_{2} \mathrm{O}_{3} / \mathrm{Fe}_{3} \mathrm{O}_{4}$ & $\begin{array}{l}\mathrm{C}_{2} \mathrm{H}_{4} \text { formed on transition } \\
\text { metal ions and converted to } \\
\text { aromatics at acid centers }\end{array}$ & $\begin{array}{l}\text { Active phase is predominantly } \\
\text { at outer surface }\end{array}$ & $(15)$ \\
\hline
\end{tabular}

appropriate TMI salt. For impregnation, aqueous solutions of ammonium paramolybdate $\left(\left(\mathrm{NH}_{4}\right)_{6} \mathrm{Mo}_{7} \mathrm{O}_{24}\right.$, Spectrum), iron (III) nitrate $\left(\mathrm{Fe}\left(\mathrm{NO}_{3}\right)_{3} \cdot 9 \mathrm{H}_{2} \mathrm{O}\right.$, Aldrich), ammonium vanadate $\left(\mathrm{NH}_{4} \mathrm{VO}_{3}\right.$, Fisher $)$, ammonium paratungstate $\left(\left(\mathrm{NH}_{4}\right)_{10} \mathrm{H}_{2}\left(\mathrm{~W}_{2} \mathrm{O}_{7}\right)_{6}\right.$, Fluka) and chromium (VI) trioxide $\left(\mathrm{CrO}_{3}\right.$, Spectrum) were used. Molybdenum (III) chloride $\left(\mathrm{MoCl}_{3}\right.$, Aldrich), iron (III) chloride $\left(\mathrm{FeCl}_{3} \cdot 6 \mathrm{H}_{2} \mathrm{O}\right.$, Spectrum), vanadium (III) chloride $\left(\mathrm{VCl}_{3}\right.$, Aldrich), tungsten (IV) chloride ( $\mathrm{WCl}_{4}$, Aldrich), and chromium (III) chloride $\left(\mathrm{CrCl}_{3} \cdot 6 \mathrm{H}_{2} \mathrm{O}\right.$, Spectrum) were used for the solid state ion exchange reaction. Impregnated samples were prepared according to the incipient wetness method, followed by drying at $90^{\circ} \mathrm{C}$ overnight and calcination at $500^{\circ} \mathrm{C}$ for $5 \mathrm{~h}$. Solid state ion-exchanged materials were prepared by physically mixing the appropriate amounts of zeolite powder and TMI-salt in a mortar, followed by drying at $90^{\circ} \mathrm{C}$ overnight and calcination at $500^{\circ} \mathrm{C}$ for $5 \mathrm{~h}$. Clearfield and Troup (19) have demonstrated that solid-solid reactions between the hydrogen form of an ion exchange material and a transition metal chloride afford an alternative method for incorporating transition metal ions into the ion exchanger. The driving force for this reaction is the formation of gaseous $\mathrm{HCl}$. The reaction of $\mathrm{MoOCl}_{4}$ with a $\mathrm{H}-\mathrm{Y}$ zeolite was found to be essentially quantitative, as determined from the amount of $\mathrm{HCl}$ that evolved from the zeolite (20). The freshly prepared TMI/H-ZSM-5 samples were then crushed and sieved to 20/45 mesh sizes.

\section{Catalyst Pretreatment and Characterization}

Reactions were carried out in a flow system, using reactors constructed from alumina tubes (Coors, AD-998, $99.8 \% \mathrm{Al}_{2} \mathrm{O}_{3}$ ) having an internal diameter of $6.4 \mathrm{~mm}$ and containing $1.0 \mathrm{~g}$ of the catalyst. To minimize the contribution from any gas phase reactions, quartz chips filled the space above and below the catalyst beds in the flow reactors. A thermocouple in a smaller alumina tube was attached to the outside wall of each of the reactors. Reactant gases, which included $10 \% \mathrm{~N}_{2} / \mathrm{CH}_{4}$ (UHP), $\mathrm{O}_{2}$ (UHP), $\mathrm{He}$ (UHP), and CO (UHP), were obtained from Matheson. The $\mathrm{CO}$ was purified to remove iron carbonyls by passing the $\mathrm{CO}$ stream at $300^{\circ} \mathrm{C}$ through an alumina tube, filled with quartz chips. The other gases were used without further purification. Gas flows were regulated by mass flow controllers (MKS Model 1159A). In the flow system, the catalyst was heated in an $\mathrm{O}_{2}$ flow at $500^{\circ} \mathrm{C}$ for $1 \mathrm{~h}$, and flushed in He for $30 \mathrm{~min}$ (flow rate of $50 \mathrm{ml} / \mathrm{min}$ ). Some catalysts were then reduced in a stream of $\mathrm{CO}$ for several hours at high temperatures (flow rate of $50 \mathrm{ml} / \mathrm{min}$ ). After calcination and eventually reduction, the catalyst was subjected to a $\mathrm{CH}_{4}$ stream at $750^{\circ} \mathrm{C}$. The GHSV was normally kept at $800 \mathrm{~h}^{-1}$, although some experiments were conducted at lower and higher GHSV's. $\mathrm{N}_{2}$ in $\mathrm{CH}_{4}$ was used as an internal standard so that the $\mathrm{CH}_{4}$ conversion could be determined accurately and the coke formation during the reaction could be 
evaluated from a carbon mass balance. Reaction mixtures were analyzed using a HP5890A gas chromatograph, equipped with a $5 \%$ Bentone 34 on Chromosorb W-AW column and a HayeSep D column. All studies were carried out at atmospheric pressure.

FT-IR spectra of the catalysts were obtained using a Perkin Elmer 2000 FT-IR spectrometer. Self-supported wafers of $10-15 \mathrm{mg} / \mathrm{cm}^{2}$ were obtained by pressing the powdered catalysts. Each wafer was mounted on a fused-quartz bracket that was placed in an IR cell. The cell was equipped with $\mathrm{KBr}$ windows and a heated region into which the wafer could be raised and pretreated under vacuum at $500^{\circ} \mathrm{C}$ for $2 \mathrm{~h}$. Spectra were recorded at room temperature after this pretreatment. The resolution was $4 \mathrm{~cm}^{-1}$, and corrections for variations in sample wafer thickness were made for all the spectra.

\section{RESULTS AND DISCUSSION}

A survey of the catalytic performances of $2.0 \mathrm{wt} \%$ transition metal ion-loaded ZSM-5 zeolites for the reaction of methane at $750^{\circ} \mathrm{C}$, in the absence of oxygen, is given in Table 2. This table summarizes the maximum methane conversion, and the maximum selectivity toward benzene, naphthalene, and aliphatic hydrocarbons (mainly $\mathrm{C}_{2}-\mathrm{C}_{3}$ hydrocarbons) as a function of the transition metal ion ( $\mathrm{Mo}, \mathrm{Fe}, \mathrm{V}, \mathrm{W}$, and $\mathrm{Cr}$ ), the preparation method (impregnation versus solid state ion exchange), and the pretreatment method (with or without $\mathrm{CO}$ prereduction at $500^{\circ} \mathrm{C}$ ). A detailed discussion of this table will be given in the next three sections. Two other sections are devoted to the influence of the zeolite acidity and the metal loading on the methane activation process.

\section{Effect of Transition Metal Ion}

The results of Table 2 clearly show that the catalytic activity is strongly dependent on the identity of the transition metal ion and the pretreatment of the material. Optimum catalytic performance was obtained for TMI/H-ZSM-5 zeolites prereduced with $\mathrm{CO}$. The activities decreased in the order: $\mathrm{Mo}>\mathrm{W}>\mathrm{Fe}>\mathrm{Cr}$. The value of 18.3 molec. $\mathrm{CH}_{4}$ reacted/metal atom/h compares favorably with the value of 17 molec. $\mathrm{CH}_{4}$ reacted/metal atom/h reported previously (14).

As an example, we will discuss the catalytic performances of V/H-ZSM-5 catalysts in more detail. The activities and product selectivities for the reaction of methane at $750^{\circ} \mathrm{C}$ and a space velocity of $800 \mathrm{~h}^{-1}$ over a $2 \mathrm{wt} \% \mathrm{~V} / \mathrm{H}-\mathrm{ZSM}-5$ catalyst are given in Fig. 1 . The catalyst was prepared by impregnation and prereduction with $\mathrm{CO}$ at $500^{\circ} \mathrm{C}$. Following an initial activation period during the first $2 \mathrm{~h}$ of reaction,

TABLE 2

Survey of the Catalytic Performances of $2.0 \mathrm{wt} \%$ Transition Metal Ion-Loaded ZSM-5 Zeolites in the Methane Reaction at $750^{\circ} \mathrm{C}$

\begin{tabular}{|c|c|c|c|c|c|c|c|}
\hline \multirow{2}{*}{$\begin{array}{l}\text { Transition } \\
\text { metal ion }\end{array}$} & \multirow{2}{*}{$\begin{array}{l}\text { Preparation } \\
\text { method }^{a}\end{array}$} & \multirow[b]{2}{*}{$\mathrm{CO}^{b}$} & \multicolumn{2}{|c|}{ Methane reaction } & \multicolumn{3}{|c|}{ Maximum selectivity (\%) } \\
\hline & & & Conversion $(\%)^{c}$ & Rate $^{d}$ & Benzene & Naphthalene & Aliphatic hydrocarbons \\
\hline \multirow{4}{*}{ Mo } & \multirow{2}{*}{ SOL } & No & 2.6 & 6.0 & 71.5 & 0 & 31.7 \\
\hline & & Yes & 7.5 & 17.4 & 71.2 & 5.9 & 32.6 \\
\hline & \multirow[t]{2}{*}{ IMP } & No & 7.6 & 17.7 & 78.4 & 8.6 & 13.1 \\
\hline & & Yes & 7.9 & 18.3 & 72.2 & 13.6 & 12.8 \\
\hline \multirow[t]{4}{*}{$\mathrm{Fe}$} & \multirow[t]{2}{*}{ SOL } & No & 0.8 & 1.2 & 0 & 0 & 17.7 \\
\hline & & Yes & 3.9 & 5.4 & 45.5 & 0 & 31.7 \\
\hline & \multirow[t]{2}{*}{ IMP } & No & 4.1 & 5.7 & 61.8 & 3.7 & 19.4 \\
\hline & & Yes & 4.1 & 5.7 & 73.4 & 16.1 & 22.1 \\
\hline \multirow[t]{4}{*}{$\mathrm{V}$} & \multirow[t]{2}{*}{ SOL } & No & 0.6 & 0.6 & 35.4 & 0 & 20.1 \\
\hline & & Yes & 0.6 & 0.6 & 35.5 & 0 & 19.1 \\
\hline & \multirow[t]{2}{*}{ IMP } & No & 0.6 & 0.6 & 63.1 & 0 & 19.8 \\
\hline & & Yes & 3.2 & 3.9 & 31.6 & 6.3 & 20.4 \\
\hline \multirow[t]{4}{*}{$\mathrm{Cr}$} & \multirow[t]{2}{*}{ SOL } & No & 0.2 & 0.3 & 0 & 0 & 20.1 \\
\hline & & Yes & 0.5 & 0.6 & 28.2 & 0 & 64.9 \\
\hline & \multirow[t]{2}{*}{ IMP } & No & 0.3 & 0.3 & 19.4 & 0 & 58.6 \\
\hline & & Yes & 1.1 & 1.5 & 72.0 & 3.7 & 26.7 \\
\hline \multirow[t]{4}{*}{$\mathrm{W}$} & \multirow[t]{2}{*}{ SOL } & No & 0.3 & 1.5 & 0 & 0 & 12.7 \\
\hline & & Yes & 2.3 & 10.2 & 40.6 & 0 & 18.5 \\
\hline & \multirow[t]{2}{*}{ IMP } & No & 0.7 & 3.0 & 0 & 0 & 16.9 \\
\hline & & Yes & 2.4 & 10.8 & 50.8 & 0 & 20.1 \\
\hline
\end{tabular}

\footnotetext{
${ }^{a}$ SOL, prepared via solid state ion-exchange; IMP, prepared via impregnation.

${ }^{b} 500^{\circ} \mathrm{C}$ for $6 \mathrm{~h}$.

${ }^{c}$ After $3 \mathrm{~h}$ of reaction.

${ }^{d}$ Molecules $\mathrm{CH}_{4}$ reacted/metal atom/h.
} 

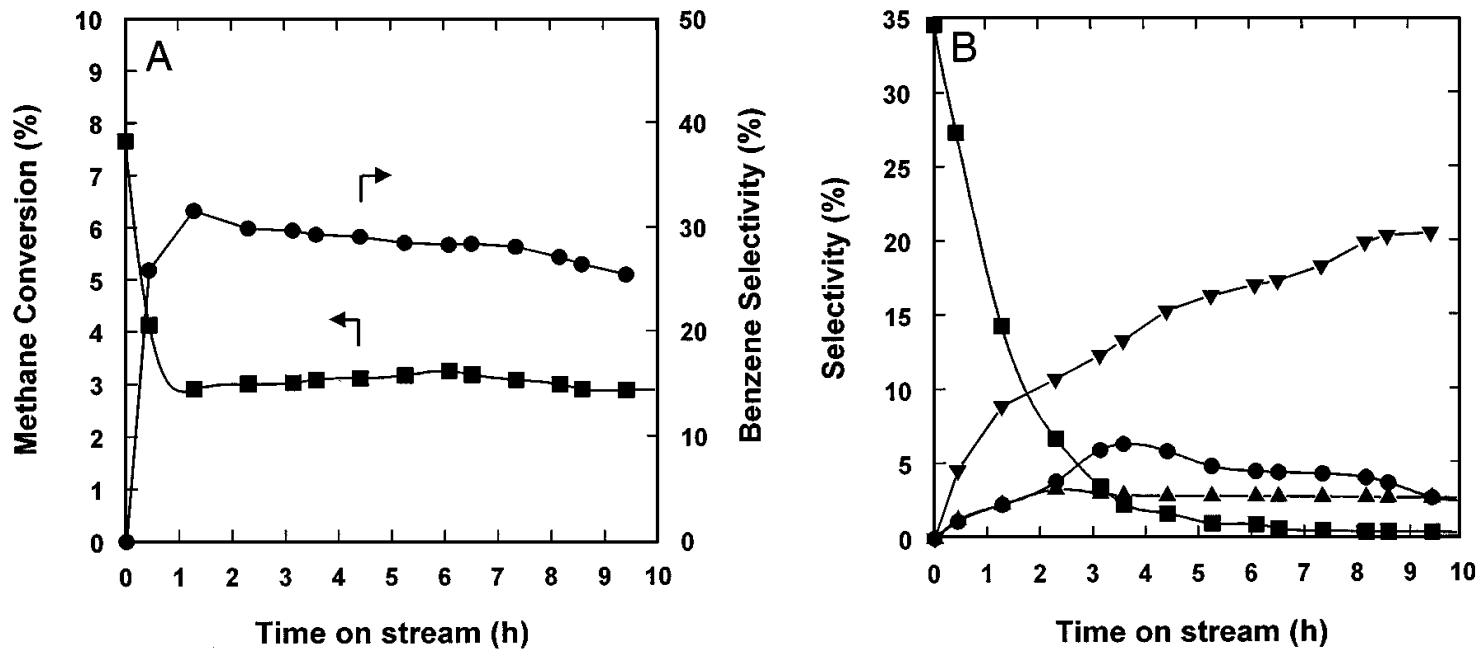

FIG. 1. (A) Methane conversion and benzene selectivity and (B) selectivities toward $\mathrm{CO}(\boldsymbol{\square})$, naphthalene ( $\bullet$ ), toluene ( $\mathbf{\Delta})$, and $\mathrm{C}_{2}-\mathrm{C}_{3}$ hydrocarbons $(\boldsymbol{\nabla})$ for $\mathrm{CH}_{4}$ reaction over $2 \mathrm{wt} \% \mathrm{~V} / \mathrm{H}-\mathrm{ZSM}-5$ prepared by impregnation and prereduced at $500^{\circ} \mathrm{C}$ for $6 \mathrm{~h}$ in $\mathrm{CO}$. The catalytic reaction was conducted at $750^{\circ} \mathrm{C}, 1 \mathrm{~atm}$, and $\mathrm{GHSV}=800 \mathrm{~h}^{-1}$.

a benzene selectivity of about $30 \%$ at a $\mathrm{CH}_{4}$ conversion of $3.2 \%$ was achieved. During the first 20 min on-stream, virtually no hydrocarbon products were formed, and the major gas-phase products were $\mathrm{CO}, \mathrm{CO}_{2}$, and $\mathrm{H}_{2} \mathrm{O}$. The amount of $\mathrm{CO}$ gradually decreased with increasing time-on-stream and was almost totally absent after $4 \mathrm{~h}$ of reaction. In addition to benzene, naphthalene, and toluene were formed, but with lower selectivities. The selectivity of naphthalene reached a value of $6 \%$ immediately following the initial activation period, but then declined slowly with increasing time-on-stream. For toluene, a maximum selectivity of $3 \%$ was observed. Thus, after a sufficiently long reaction time, mainly benzene, and some toluene and naphthalene was produced, and the maximum selectivity toward aromatic hydrocarbons was higher than $36 \%$. On the other hand, the selectivity toward $\mathrm{C}_{2}-\mathrm{C}_{3}$ hydrocarbons (mainly ethylene) increased continuously with increasing reaction time, as coke deposition gradually deactivated the acidic sites in the zeolite, where the ethylene undergoes secondary reaction. The formation of coke was confirmed by evaluating the carbon mass balance during methane activation.

\section{Effect of Catalyst Preparation}

Catalysts prepared by solid state ion exchange always had a lower catalytic activity (Table 2), and, because of experimental uncertainty, a more erratic selectivity pattern than those prepared by impregnation. This is illustrated by comparing the results of Fig. 1 with those of Fig. 2, which were
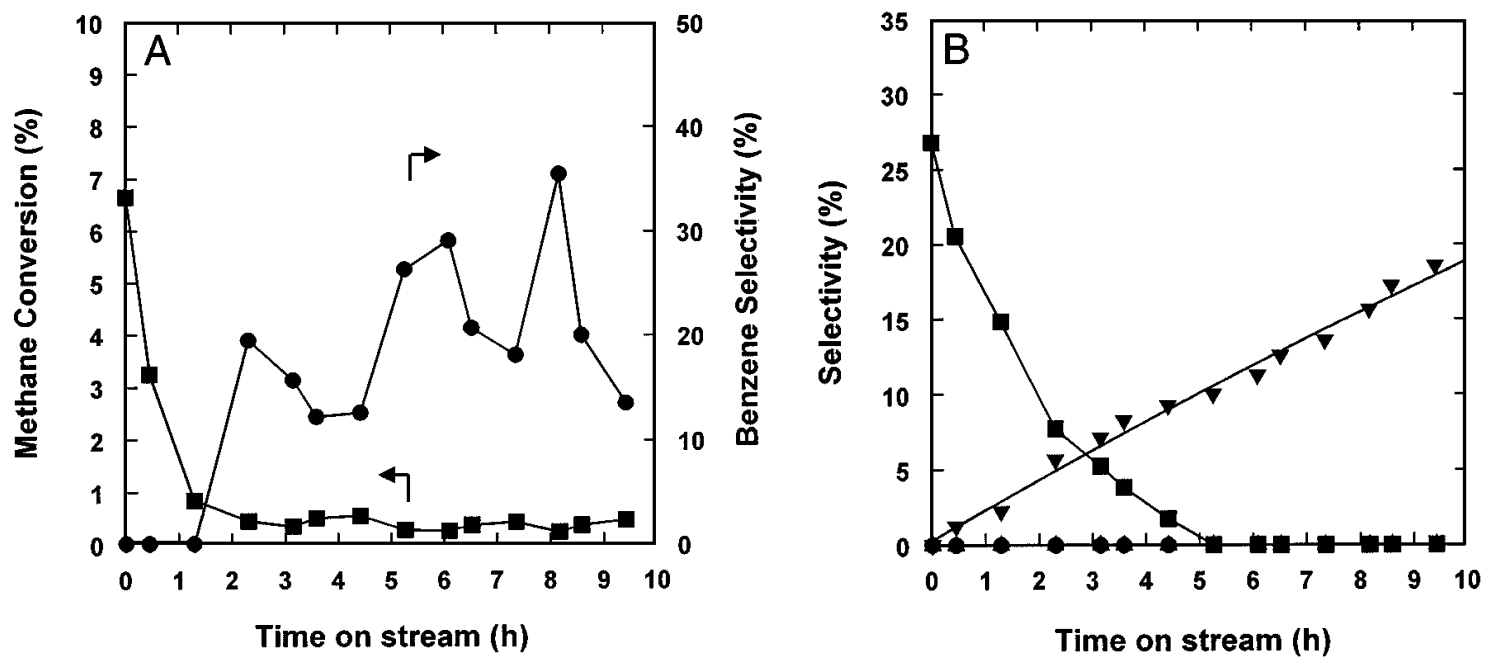

FIG. 2. (A) Methane conversion and benzene selectivity and (B) selectivities toward $\mathrm{CO}(\boldsymbol{\square})$, naphthalene $(\boldsymbol{\bullet})$, toluene $(\boldsymbol{\Delta})$, and $\mathrm{C}_{2}-\mathrm{C}_{3}$ hydrocarbons $(\boldsymbol{\nabla})$ for $\mathrm{CH}_{4}$ reaction over $2 \mathrm{wt} \% \mathrm{~V} / \mathrm{H}-\mathrm{ZSM}-5$ prepared by solid state ion exchange and prereduced at $500^{\circ} \mathrm{C}$ for $6 \mathrm{~h}$ in $\mathrm{CO}$. The catalytic reaction was conducted at $750^{\circ} \mathrm{C}, 1 \mathrm{~atm}$, and $\mathrm{GHSV}=800 \mathrm{~h}^{-1}$. 
obtained for a $2 \mathrm{wt} \% \mathrm{~V} / \mathrm{H}-\mathrm{ZSM}-5$ catalyst that had been prepared by solid state ion exchange. Following an initial activation period, a benzene selectivity ranging between 13 and $36 \%$ at methane conversion of $0.6 \%$ was achieved. No toluene and naphthalene were formed during methane activation, suggesting that higher aromatic compounds, such as naphthalene cannot be formed in the partially blocked zeolite channels. Indeed, solid state ion exchange may lead to some local lattice destruction $(16,17)$, which can prevent the formation of the larger naphthalene within the zeolite channels. In addition to benzene, $\mathrm{C}_{2}-\mathrm{C}_{3}$ hydrocarbons were produced, and the selectivity towards these products increased continuously with increasing reaction time.

The lower methane conversion over the solid state ionexchanged materials can be explained by comparing the hydroxyl region of the zeolites, as measured by FT-IR spectroscopy. As an example, we will discuss in detail the $2 \mathrm{wt} \%$ V/H-ZSM-5 zeolites, prepared by both impregnation and solid state ion exchange; however, similar results were obtained for the other catalytic systems. The parent H-ZSM-5 material possessed three distinguishable hydroxyl bands after calcination. One of these, having a vibrational frequency of $3610 \mathrm{~cm}^{-1}$, is associated with the Brönsted acidity of the zeolite (21-23). A second hydroxyl group, having a stretching frequency of $3745 \mathrm{~cm}^{-1}$, has been attributed to silanol groups that terminate the zeolite lattice. These hydroxyl groups are predominantly located at the outer surface of the zeolite $(21,22)$. A weaker band at around $3670 \mathrm{~cm}^{-1}$ is due to hydroxyl groups that are associated with extraframework aluminum species (24). Addition of $2 \mathrm{wt} \%$ vanadium, followed by calcination, resulted in an overall decrease in amplitudes of the hydroxyl bands of the zeolite material; however, the relative intensity decrease of the three hydroxyl groups was dependent on the preparation method. In the case of solid state ion-exchanged materials, the bands at 3610 and $3670 \mathrm{~cm}^{-1}$ were strongly affected, while for the impregnated samples, predominantly the intensity of the $3745 \mathrm{~cm}^{-1}$ band decreased. Thus, in samples prepared by impregnation, vanadium preferentially reacts with the silanol groups at the outer surface of the zeolite. Materials prepared by solid-state ion exchange, on the other hand, did not possess many Brönsted acid sites after calcination. This is due to the reaction of vanadium chloride with the Brönsted acid sites during preparation to form the cation at the exchange site plus some gas phase $\mathrm{HCl}$. As a consequence, the differences in catalytic activity/selectivity between impregnated and solid state ion-exchanged materials can be explained in terms of differences in zeolite acidity and the state of the transition metal ion. In the case of solid state ion-exchanged zeolites, the metal ions were predominantly located in the zeolite channels at ion exchange sites. For catalysts prepared by impregnation, the transition metal ions were preferentially anchored at the outer surface, probably as small clusters or a thin film of the ox- ide, and only a fraction diffused into the zeolite channels where they replaced the protons at Brönsted acid sites.

\section{Effect of Catalyst Pretreatment}

The results of Table 2 also show that methane activation was strongly influenced by catalyst prereduction, and that CO-prereduced catalysts were always the most active materials, except for Fe/H-ZSM-5 prepared by impregnation, for which pretreatment in $\mathrm{CO}$ did not improve the activity. This is nicely illustrated by considering the catalytic performance of solid state ion-exchanged Fe/H-ZSM-5 catalysts. As indicated in Table 2, this material possessed almost no catalytic activity prior to $\mathrm{CO}$ treatment. Only after prereducing the catalyst with $\mathrm{CO}$ at $500^{\circ} \mathrm{C}$, was a benzene selectivity of more than $40 \%$ achieved at a methane conversion of about $3.9 \%$.

The effect of $\mathrm{CO}$ reduction is further illustrated in Fig. 3, which describes the results obtained during a catalytic reaction for $4 \mathrm{~h}$ at $750^{\circ} \mathrm{C}$ over a nonprereduced solid state ion-exchanged $2 \mathrm{wt} \% \mathrm{Fe} / \mathrm{H}-\mathrm{ZSM}-5$ catalyst. The methane activity decreased to zero after $4 \mathrm{~h}$ on-stream, and no benzene formation was detected for a period up to $10 \mathrm{~h}$. The sample was then cooled to $500^{\circ} \mathrm{C}$ and treated with $\mathrm{CO}$ for $6 \mathrm{~h}$. After this treatment step, the catalyst was again heated to $750^{\circ} \mathrm{C}$ in a flow of helium, and then subjected to methane for $10 \mathrm{~h}$. After an initial activation period of about $2 \mathrm{~h}$, a benzene selectivity of $42 \%$ was reached at a methane conversion of $4.1 \%$. During the first 30 min on stream, no benzene was detected, and the major gas-phase products were $\mathrm{CO}, \mathrm{CO}_{2}$, and $\mathrm{H}_{2} \mathrm{O}$. In addition to benzene, $\mathrm{C}_{2}-\mathrm{C}_{3}$ hydrocarbons, mainly ethylene, were formed. However, neither naphthalene nor toluene were detected. After a sufficiently long reaction time, the methane conversion and

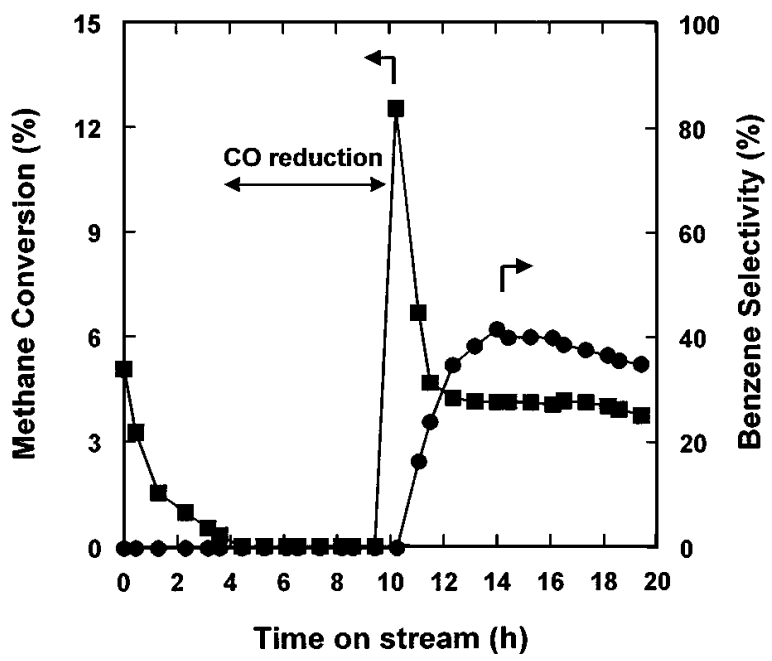

FIG. 3. Methane conversion and benzene selectivity results for $\mathrm{CH}_{4}$ reaction over $2 \mathrm{wt} \% \mathrm{Fe} / \mathrm{H}-\mathrm{ZSM}-5$ prepared by solid state ion exchange. The catalytic reaction was at $750^{\circ} \mathrm{C}, 1 \mathrm{~atm}$, and $\mathrm{GHSV}=800 \mathrm{~h}^{-1}$. 


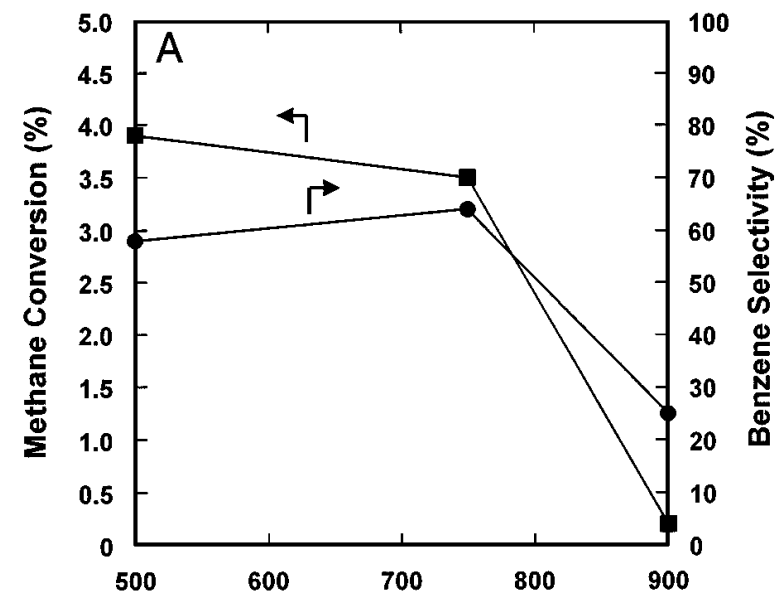

Reduction Temperature $\left({ }^{\circ} \mathrm{C}\right)$

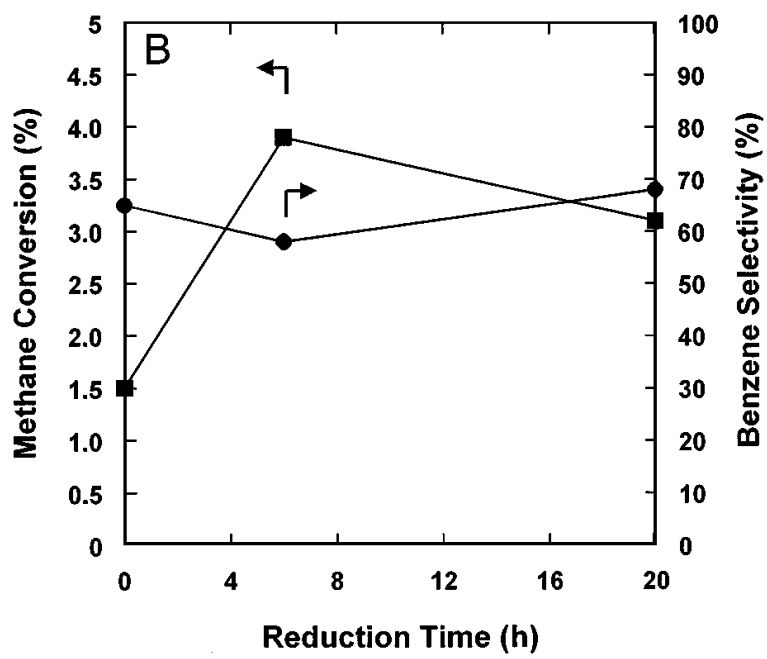

FIG. 4. (A) Effect of reduction temperature and (B) reduction time on the conversion of methane over 2.0 wt $\%$ Fe/H-ZSM-5 prepared by impregnation. The catalytic reaction was at $750^{\circ} \mathrm{C}, 1 \mathrm{~atm}$, and $\mathrm{GHSV}=800 \mathrm{~h}^{-1}$. For experiment $\mathrm{A}$, the reduction time was $6 \mathrm{~h}$, whereas the reduction temperature was $500^{\circ} \mathrm{C}$ for experiment $\mathrm{B}$.

benzene selectivity decreased, while the selectivity toward $\mathrm{C}_{2}-\mathrm{C}_{3}$ hydrocarbons increased continuously with increasing reaction time. Thus, catalytically inactive materials can be made active by pretreating the catalyst with $\mathrm{CO}$. This observation suggests that $\mathrm{CO}$ treatment, although necessary to reduce the metal ion to the catalytically active state, also influences the dispersion of the transition metal ion. As will be shown in part II of this study (18), CO treatment at high temperature resulted in an enrichment of the transition metal ion at the outer surface of the zeolite. The water produced during the early states of the subsequent reaction with $\mathrm{CH}_{4}$ must reintroduce Brönsted acid sites into the ion-exchanged material.

The time and temperature of reduction are also important, as illustrated in Fig. 4. This figure shows that increasing the reduction temperature to $750^{\circ} \mathrm{C}$ resulted in a slight increase in benzene selectivity; however, both the activity and selectivity decreased significantly at higher reduction temperatures. Almost no methane conversion was observed after reducing the catalyst for $6 \mathrm{~h}$ at $900^{\circ} \mathrm{C}$. This must be due to carbon deposition via the Boudouard reaction. It is also important to stress that higher reduction temperatures resulted in a shortening of the initial induction time for catalysts prepared by impregnation.

In another series of experiments, the effects of calcination temperature and reaction temperature on the catalytic performance of $0.6 \mathrm{wt} \% \mathrm{Fe} / \mathrm{H}-\mathrm{ZSM}-5$ catalysts were studied. The results are shown in Figs. 5 and 6. It is clear from Fig. 5 that a reasonably constant conversion could be obtained by calcining the catalysts between 500 and $700^{\circ} \mathrm{C}$ in oxygen. Calcination temperatures at $900^{\circ} \mathrm{C}$, however, resulted in a catalytically inactive material. This deactivation must be due to lattice destruction and/or thermal condensation of Brönsted acid sites. This has recently been proven for Mo/H-ZSM-5 catalysts by Liu et al. (25). The methane conversion increased with increasing reaction temperature (Fig. 6), but the selectivity for benzene decreased below $40 \%$ at a reaction temperature of $800^{\circ} \mathrm{C}$. At higher reaction temperatures, hydrocarbons partially converted to coke. Thus, methane activation becomes less selective at higher reaction temperatures, which is disappointing because the equilibrium conversion of methane to aromatics increases with increasing temperature (14).

The methane conversion and the selectivity toward benzene increased with decreasing space velocity of methane as shown in Fig. 7. At a gas hourly space velocity (GHSV)

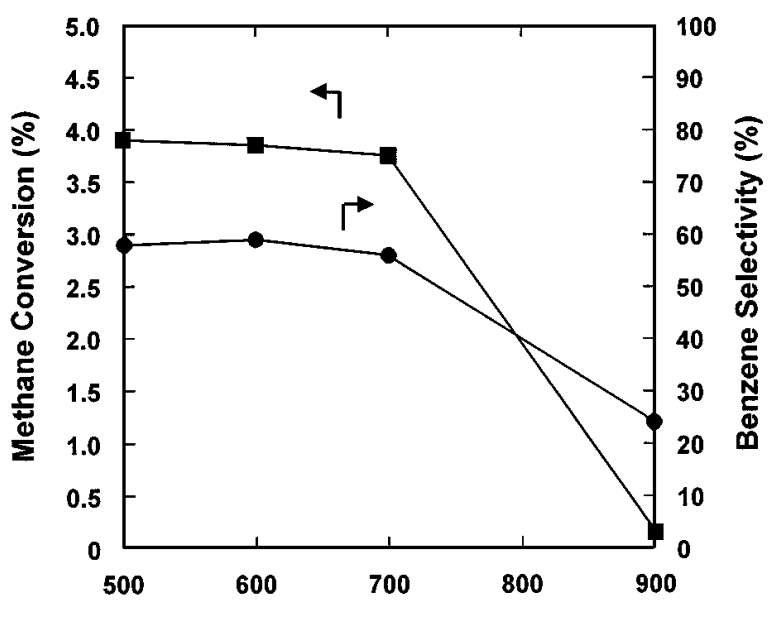

Calcination Temperature $\left({ }^{\circ} \mathrm{C}\right)$

FIG. 5. Effect of calcination temperature on $\mathrm{CH}_{4}$ activation over $0.6 \mathrm{wt} \% \mathrm{Fe} / \mathrm{H}-\mathrm{ZSM}-5$ prepared by impregnation and prereduced at $500^{\circ} \mathrm{C}$ for $6 \mathrm{~h}$ in $\mathrm{CO}$. The catalytic reaction was at $750^{\circ} \mathrm{C}, 1 \mathrm{~atm}$, and GHSV = $800 \mathrm{~h}^{-1}$. 


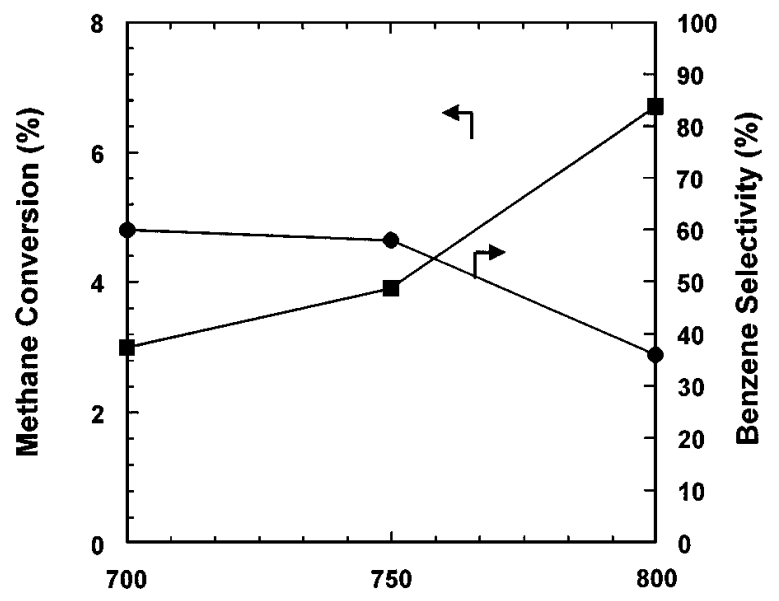

Reaction Temperature $\left({ }^{\circ} \mathrm{C}\right)$

FIG. 6. Effect of reaction temperature on the conversion of methane over $0.6 \mathrm{wt} \% \mathrm{Fe} / \mathrm{H}-\mathrm{ZSM}-5$ prepared by impregnation and prereduced at $500^{\circ} \mathrm{C}$ for $6 \mathrm{~h}$ in $\mathrm{CO}$. The catalytic reaction was at $1 \mathrm{~atm}$ and GHSV $=$ $800 \mathrm{~h}^{-1}$.

of $400 \mathrm{~h}^{-1}$, a benzene selectivity of $70 \%$ at a methane conversion of about $6.8 \%$ was achieved over a $0.6 \mathrm{wt} \% \mathrm{Fe} / \mathrm{H}-$ ZSM-5 catalyst. Furthermore, the selectivity toward $\mathrm{C}_{2}-\mathrm{C}_{3}$ hydrocarbons, mainly ethylene, decreased with decreasing space velocity. This implies that ethylene is the initial product of methane activation and, that aromatics, such as benzene, are formed by subsequent reaction of ethylene, as described previously (14).

\section{Effect of Zeolite Acidity}

The effect of the number of Brönsted acid sites on methane activation over $2 \mathrm{wt} \% \mathrm{Cr} / \mathrm{H}-\mathrm{ZSM}-5$ zeolites was studied by preparing zeolite materials differing in their

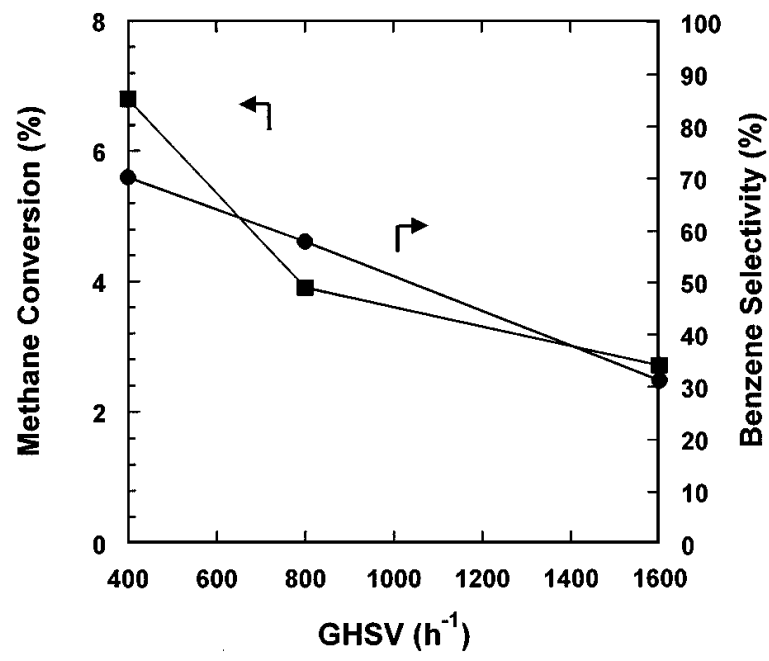

FIG. 7. Effect of GHSV on the conversion of methane over $0.6 \mathrm{wt} \%$ $\mathrm{Fe} / \mathrm{H}-\mathrm{ZSM}-5$ prepared by impregnation and prereduced at $500^{\circ} \mathrm{C}$ for $6 \mathrm{~h}$ in $\mathrm{CO}$. The catalytic reaction was at $750^{\circ} \mathrm{C}$ and $1 \mathrm{~atm}$.

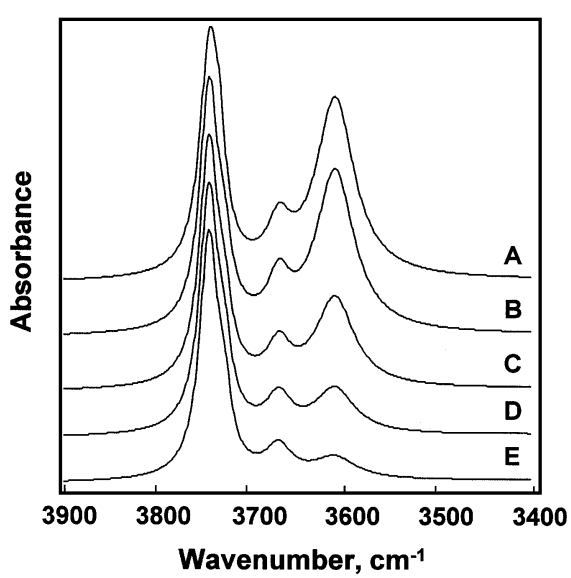

FIG. 8. Infrared spectra of $2 \mathrm{wt} \% \mathrm{Cr} / \mathrm{H}-\mathrm{ZSM}-5$ zeolites that contained different concentrations of Brönsted acid sites. Samples were prepared by ion exchange in $1 M$ solutions containing (A) $\mathrm{NH}_{4} \mathrm{NO}_{3}$, (B) $5: 1$ $\mathrm{NH}_{4} \mathrm{NO}_{3}: \mathrm{NaCl}$, (C) $3: 1 \mathrm{NH}_{4} \mathrm{NO}_{3}: \mathrm{NaCl}$, (D) $2: 1 \mathrm{NH}_{4} \mathrm{NO}_{3}: \mathrm{NaCl}$, and (E) $\mathrm{NaCl}$. Materials were subsequently impregnated with $\mathrm{CrO}_{3}$, dried and calcined at $500^{\circ} \mathrm{C}$ for $5 \mathrm{~h}$.

$\mathrm{Na}^{+}: \mathrm{H}^{+}$ratio, and consequently, in their number of Brönsted acid sites. The number of Brönsted acid sites, expressed as a percentage relative to a fully exchanged H-ZSM-5 zeolite, was determined by measuring the intensity of the $3610 \mathrm{~cm}^{-1}$ band of the calcined catalyst from the FT-IR spectra shown in Fig. 8. The number of Brönsted acid sites, together with the methane conversion and benzene selectivity, is given in Fig. 9. It is clear that methane conversion and benzene selectivity were close to zero if the zeolite material had almost no Brönsted acid sites. Furthermore, an increasing number of Brönsted $\mathrm{OH}$-groups resulted in a gradual increase in methane conversion and benzene formation, and the Cr/H-ZSM-5 catalyst without any added

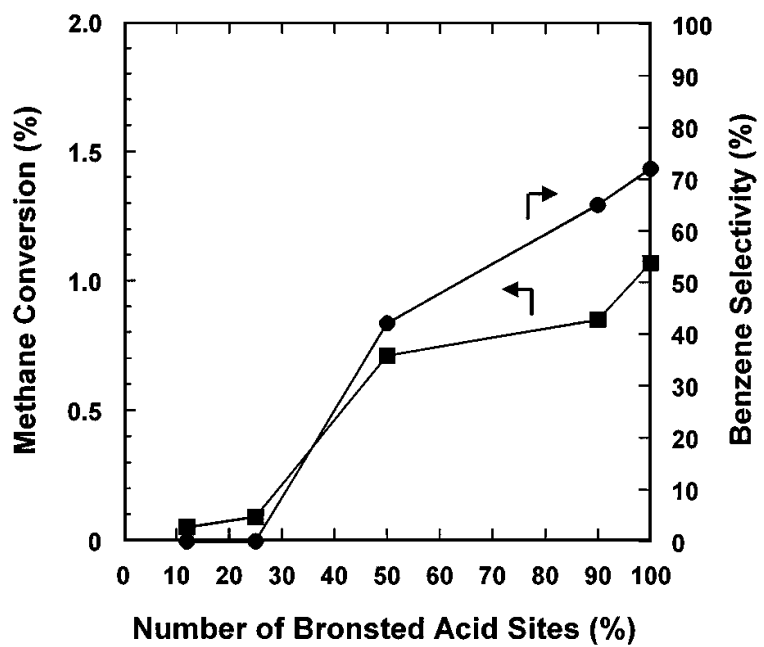

FIG. 9. Effect of the number of Brönsted acid sites on $\mathrm{CH}_{4}$ activation over $2 \mathrm{wt} \% \mathrm{Cr} / \mathrm{H}-\mathrm{ZSM}-5$ prepared by impregnation and prereduced at $500^{\circ} \mathrm{C}$ for $6 \mathrm{~h}$ in $\mathrm{CO}$. The catalytic reaction was at $750^{\circ} \mathrm{C}, 1 \mathrm{~atm}$, and $\mathrm{GHSV}=800 \mathrm{~h}^{-1}$. 
sodium possessed a maximum benzene selectivity of $72 \%$ at a conversion of $1.1 \%$. The present observations, together with results of a previous study in which we have shown that ethylene can be converted over Mo/H-ZSM-5 zeolites (13), confirm the crucial role of acid sites in methane activation. The Brönsted acid sites are responsible for oligomerizing and converting the initially formed ethylene into benzene, toluene, and naphthalene. By doing so, the acid sites shift the thermodynamically unfavorable equilibrium for the formation of ethylene to a more favorable equilibrium for the formation of aromatics. Wang et al. (5) also observed this effect by studying Mo/H-ZSM-5 zeolites with different $\mathrm{Si}$ : Al ratios. They found an increase in methane conversion with decreasing Si: Al ratio, i.e., with an increasing number of Brönsted acid sites.

\section{Effect of Metal Loading}

The catalytic performances are not only determined by the preparation and treatment conditions, and by the zeolite acidity, but also by the overall amount of transition metal ions. As an example, we will discuss the $\mathrm{Cr} / \mathrm{H}-\mathrm{ZSM}-5$ system in more detail. Similar results were observed for other transition metal ions, although the exact optimum metal loading is dependent on the transition metal ion (e.g., around $4 \mathrm{wt} \%$ for Mo). The effect of the Cr loading on the methane activation and benzene selectivity is given in Fig. 10. It is clear that maximum catalytic activity was obtained at around $2 \mathrm{wt} \%$ and that higher $\mathrm{Cr}$ loadings did not result in more active materials. However, the selectivity toward benzene gradually increased with increasing $\mathrm{Cr}$ loading and leveled off at the highest $\mathrm{Cr}$ loading, i.e., $6 \mathrm{wt} \%$. It is important to note here that the highly loaded materials, prepared by impregnation, contained Brönsted acid sites, as indicated by FT-IR spec-

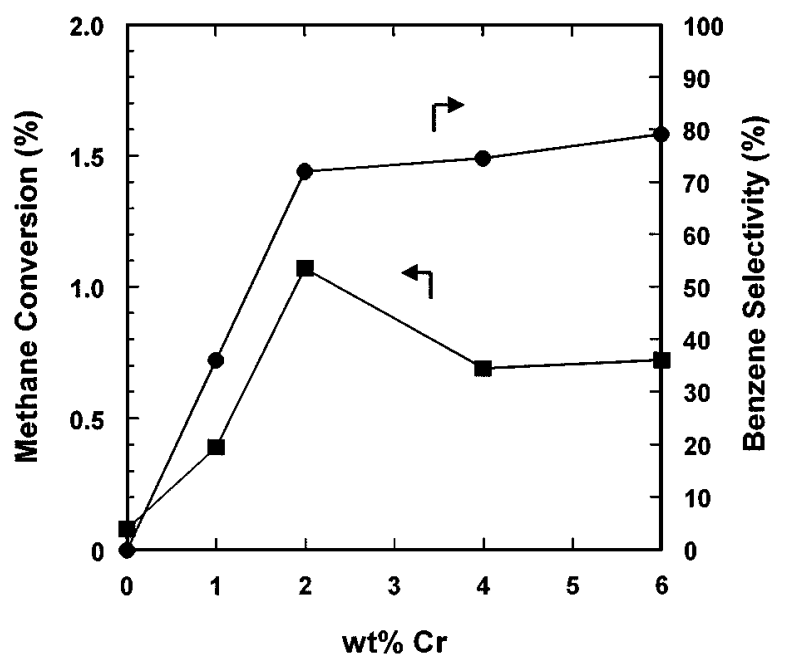

FIG. 10. Effect of $\mathrm{Cr}$ loading on $\mathrm{CH}_{4}$ activation and benzene selectivity over $\mathrm{Cr} / \mathrm{H}-\mathrm{ZSM}-5$ prepared by impregnation and prereduced at $500^{\circ} \mathrm{C}$ for $6 \mathrm{~h}$ in $\mathrm{CO}$. The catalytic reaction was at $750^{\circ} \mathrm{C}, 1 \mathrm{~atm}$, and $\mathrm{GHSV}=800 \mathrm{~h}^{-1}$. troscopy. This suggests that there are still enough Brönsted acid sites available to convert the initially formed ethylene to aromatic compounds.

One can speculate as to why the methane conversion goes through a maximum. The most likely hypothesis is that the dispersion of the active $\mathrm{CrO}_{\mathrm{x}}$ phase decreases with increasing $\mathrm{Cr}$ loading. Indeed, detailed spectroscopic investigations of extensively loaded $\mathrm{Cr}$-zeolites show a low $\mathrm{Cr}^{\mathrm{n}+}$ dispersion, as indicated by the formation of $\alpha-\mathrm{Cr}_{2} \mathrm{O}_{3}$ (26). Another possible reason is lattice destruction. Pearce and Mortier (27) have shown by XRD that the introduction of $\mathrm{Cr}^{3+}$ in zeolites $\mathrm{A}$ and $\mathrm{X}$ resulted in lattice destruction, especially at higher $\mathrm{Cr}$ loadings. Recently, Liu et al. (25) concluded from detailed NMR studies on $\mathrm{Mo} /$ $\mathrm{H}-\mathrm{ZSM}-5$ catalysts that the extractability of framework $\mathrm{Al}$ by Mo species increases with increasing Mo loading. The extraction process leads to the formation of nonframework $\mathrm{Al}$ at first, and then to the formation of a new crystalline phase of $\mathrm{Al}_{2}\left(\mathrm{MoO}_{4}\right)_{3}$. These materials were always catalytically inferior for methane activation.

Another interesting observation is that the induction time for the Cr/H-ZSM-5 materials decreased with increasing $\mathrm{Cr}$ loading, independent of the treatment and preparation condition. It is known that increasing $\mathrm{Cr}$ loading results in an increase of the polychromate:monochromate ratio on the zeolitic surfaces and that surface polychromates are more readily reducible than surface monochromates (26). In other words, the shorter induction times can be explained in terms of differences in redox behavior of supported $\mathrm{CrO}_{\mathrm{x}}$.

\section{CONCLUSIONS}

1. Mo-, Fe-, V-, W-, and Cr-loaded H-ZSM-5 zeolites are able to selectively convert methane to aromatics, and the activity decreased in the order: $\mathrm{Mo}(18.3)>\mathrm{W}(10.8)>\mathrm{Fe}$ (5.7) $>\mathrm{V} \mathrm{(3.9)}>\mathrm{Cr}$ (1.5), where the numbers in parentheses are the rates of methane reaction (molec. reacted/metal atom $/ \mathrm{h}$ ) obtained after $3 \mathrm{~h}$ on-stream.

2. The induction period, prior to the formation of benzene, toluene, and naphthalene, decreases with increasing metal ion loading.

3. The catalytic activity is directly proportional to the number of Brönsted acid sites. These sites are responsible for the oligomerization and dehydrocyclization of the primary ethylene product.

4. The catalytic performance is strongly dependent on the preparation method, the treatment condition, and the metal loading. The activity of catalysts prepared by impregnation is always higher than that of solid state ionexchanged materials. Furthermore, inactive materials were made active by pretreatment with $\mathrm{CO}$. Optimum activity was obtained for $2-4 \mathrm{wt} \% \mathrm{TMI} / \mathrm{H}-\mathrm{ZSM}-5$ materials. The state of the metal, as determined by X-ray photoelectron 
spectroscopy, will be described more fully in part II of this study.

5. The supported transition metal ions are predominantly located in the zeolite channels of solid state ion materials. These materials have only a small amount of Brönsted acidity. For samples prepared by impregnation, the supported transition metal ions are mainly located at the outer surface, and only a fraction diffuses into the channels of the zeolite material.

\section{ACKNOWLEDGMENTS}

This work was sponsored by the National Science Foundation, under Grant CHE-9520806. B.M.W. is a postdoctoral research fellow of the Belgian National Fund of Scientific Research.

\section{REFERENCES}

1. Lunsford, J. H., Angew. Chem. Int. Ed. Engl. 34, 970 (1995).

2. Lunsford, J. H., Stud. Surf. Sci. Catal. 75, 103 (1993).

3. Bragin, A. V., Vasina, T. V., Preobrazhenskii, A. V., and Minachev, K. M., Izv. Akad. Nauk SSSR Ser. Khim. 3, 750 (1989).

4. Vasina, T. V., Preobrazhenskii, A. V., Isaev, S. A., Chetina, O. V., and Masloboishchikova, Bragin, O. V., Kinet. Catal. 35, 93 (1994).

5. Wang, L., Tao, L., Xie, M., Xu, G., Huang, J., and Xu, Y., Catal. Lett. 21, 35 (1993).

6. Xu, Y., Liu, S., Wang, L., Xie, M., and Guo, X., Catal. Lett. 30, 135 (1995).

7. Xu, Y., Liu, W., Wong, S., Wang, L., and Guo, X., Catal. Lett. 40, 207 (1996).
8. Chen, L., Lin, L., Xu, Z., Li, Z., and Zhang, T., J. Catal. 157, 190 (1995).

9. Chen, L., Li, L., Xu, Z., Zhang, T., and Li, X., Catal. Lett. 39, 169 (1996).

10. Solymosi, F., Erdohelyi, A., and Szoke, A., Catal. Lett. 32, 43 (1995).

11. Solymosi, F., Szoke, A., and Cserenyi, J. Catal. Lett. 39, 157 (1996).

12. Solymosi, F., Cserenyi, J., Szoke, A., Bansagi, T., and Oszko, A., J. Catal. 165, 150 (1997).

13. Wang, D., Rosynek, M. P., and Lunsford, J. H., Top. Catal. 3, 289 (1996).

14. Wang, D., Rosynek, M. P., and Lunsford, J. H., J. Catal. 169, 347 (1997).

15. Weckhuysen, B. M., Wang, D., Rosynek, M. P., and Lunsford, J. H., Angew. Chem., Int. Ed. Engl. 36, 2374 (1997).

16. Karge, H. G., and Beyer, H. K., in "Zeolite Chemistry and Catalysis" (P. A. Jacobs et al., Ed.), p. 43. Elsevier Science, Amsterdam, 1991.

17. Kucherov, A. V., and Slinkin, A. A., J. Mol. Catal. 90, 323 (1994).

18. Weckhuysen, B. M., Wang, D., Rosynek, M. P., and Lunsford, J. H., J. Catal. 175(1) (1998).

19. Clearfield, A., and Troup, J. M., J. Phys. Chem. 74, 2578 (1970).

20. Dai, P.-S. E., and Lunsford, J. H., J. Catal. 64, 173 (1980).

21. Vedrine, J. C., Auroux, A., Bolis, V., Dajaifve, P., Naccache, C., Wierzchowski, P., Derouane, E. G., Nagy, J. B., Gilson, J., van Hooff, J., van den Berg, J. P., and Wolthuizen, J., J. Catal. 59, 248 (1979).

22. Topsoe, N., Pedersen, K., and Derouane, E. G., J. Catal. 70, 41 (1981).

23. Jacobs, P. A., and von Ballmoos, R., J. Phys. Chem. 86, 3050 (1982).

24. Campbell, S. M., Bibby, D. M., Coddington, J. M., Howe, R. F., and Meinhold, R. H., J. Catal. 161, 338 (1996).

25. Liu, W., Xu, Y., Wang, S. T., Wang, L., Qiu, J., and Yang, N., J. Mol. Catal. A: Chemical 120, 257 (1997).

26. Weckhuysen, B. M., Wachs, I. E., and Schoonheydt, R. A., Chem. Rev. 96, 3327 (1996).

27. Pearce, J. R., and Mortier, W. J., J. Chem. Soc., Faraday Trans. 1 77, 1935 (1981). 